\title{
Mammals of the Tamaulipeco Thorny Scrubland, Northwestern Coahuila, Mexico
}

\author{
M. Vianey Gómez-Naranjo', M. Ángel León-Tapia² and Yolanda Hortelano-Moncada*2 \\ ${ }^{1}$ Facultad de Ciencias, Universidad Nacional Autónoma de México. Circuito exterior s/n, CP. 04510. Ciudad de México, México. \\ Email: vian biol@ciencias.unam.mx (MVGN) \\ ${ }^{2}$ Instituto de Biología, Departamento de Zoología, Universidad Nacional Autónoma de México. Circuito exterior s/n, CP. 04510. \\ Ciudad de México, México. Email: mal@st.ib.unam.mx (MALT), yolahm@ib.unam.mx (YHM) \\ ${ }^{*}$ Corresponding author
}

The 'Tamaulipeco' thorny scrubland is one of the most interesting habitats of northeastern Mexico. It is considered that almost $70 \%$ of its original surface area has been lost. Although there are no formal studies about the side effects of this loss, it is likely that it threatens wildlife in this habitat, mammals included. In addition, few areas in the State of Coahuila have been properly documented. The aim of this study was to document the richness of wild mammals in the northeastern border of Coahuila within the priority terrestrial region known as "Tamaulipeco Scrubland of the Lower Rio Bravo". The richness of mammals was assessed through direct records by trapping methods for small, mediumsized and large mammals along with the use of camera traps. This was supplemented with indirect records through traces. The occurrence index and richness of the area index were calculated. In addition, dominance and evenness were both evaluated with the Simpson and the Shannon-Wiener indexes for small and medium-sized/large mammals separately. Thirty three mammal species (Table 2) were recorded in 34 days of recording effort. The richness recorded in the study area represents $31.8 \%$ of the mammal wildlife reported for Coahuila. The high diversity in the area is evidenced by the Margalef index (5.13). The Simpson index for small mammals (0.241) indicates a higher dominance in relation to medium-sized/large mammals (0.215). The Shannon-Wiener index showed a lower evenness among small relative to medium-sized /large mammal species (1.821 vs. 1.858). The species richness recorded in the study area shows a high diversity supported by the Margalef index. Despite characteristics of some of the observed traces are inarguable for specie's identification index does not confirm its presence due to low indirect records, so the certain presence of these species need to be confirmed in future surveys. The large number of records for Dicotyles angulatus and Odocoileus virginianus is due to the location of the study area in a hunting zone were these are the main species hunted. It is likely that hunting activities by local inhabitants benefits the rest of the species recorded.

El matorral espinoso tamaulipeco es uno de los hábitats característicos del noreste de México. Se considera que cerca del $70 \%$ de su superficie original se ha perdido. Aunque no existen estudios formales sobre sus efectos negativos, es probable que su pérdida ponga en peligro la fauna presente en este tipo de vegetación, incluidos los mamíferos. Sumado a esto, algunas regiones del estado de Coahuila no han sido bien documentadas. El objetivo del presente estudio fue conocer la riqueza de los mamíferos silvestres presentes en el límite noreste de Coahuila dentro de la región terrestre prioritaria "Matorral Tamaulipeco del Bajo Río Bravo". La riqueza de mamíferos se obtuvo mediante registros directos a través de la captura con trampas con cebo para mamíferos de tamaño pequeño, mediano y grande, además del uso de cámaras trampa. Se complementó con registros indirectos por medio de búsqueda de rastros. Se calculó el índice de ocurrencia y el índice de Margalef. Además, se evaluó la dominancia y la equidad mediante los índices de Simpson y Shannon-Wiener para los mamíferos pequeños y los medianos y grandes por separado. Con un esfuerzo de muestreo de 34 días se registraron 33 especies de mamíferos (Tabla 2). La riqueza en el área representa el 31.8 \% de la mastofauna reportada para Coahuila. El índice de Margalef (5.13) mostró que la diversidad de la zona es alta. El índice de Simpson en los mamíferos pequeños (0.241) indica una mayor dominancia de las especies más abundantes con respectos a los mamíferos medianos y grandes (0.215). El índice de Shanon-Wiener mostró que la equidad entre especies fue menor en los mamíferos pequeños (1.821) que en los de tamaño mediano y grande (1.858). La riqueza registrada en el área de estudio demuestra la diversidad alta en la zona que es soportada por el índice de Margalef. A pesar de que las características de algunos de los rastros observados son indiscutibles para la identificación de la especie, el índice de ocurrencia no confirma su presencia debido al bajo número de registros indirectos de esas especies, por lo que la certera presencia de éstas debe corroborarse con futuros trabajos. El número alto de registros de Dicotyles angulatus y Odocoileus virginianus se debe a que el área de estudio está inmersa en una zona cinegética donde éstas son las principales especies utilizadas. Es probable que las actividades cinegéticas realizadas por los locatarios estén beneficiando al resto de las especies reportadas.

Key words: Camera trap; hunting; mammals; occurrence index; richness.

(C) 2017 Asociación Mexicana de Mastozoología, www.mastozoologiamexicana.org

\section{Introduction.}

Northeastern Mexico comprises the States of Coahuila, Nuevo León, San Luis Potosí and Tamaulipas, and includes an interesting complex of habitats. One of these is the arid zone located in the boundary with the United States of America, which encompasses two vegetation types: the Chihuahuan desert of western Mexico and the Tamaulipeco thorny scrubland to the east (Rzedowski 2006). The latter has an approximate area of $\sim 200.000 \mathrm{~km}^{2}$ distributed in the States of Coahuila, Nuevo Leon and Tamaulipas, in Mexico, and southern Texas in the United States of America (Jiménez et al. 2012). Although this area is home to a high diversity of plant species, this vegetation type is currently considered as threatened by anthropogenic activities such as cattle raising (intensive/extensive), agriculture and different forest activities that have led to the loss in terms of habitat quality and 


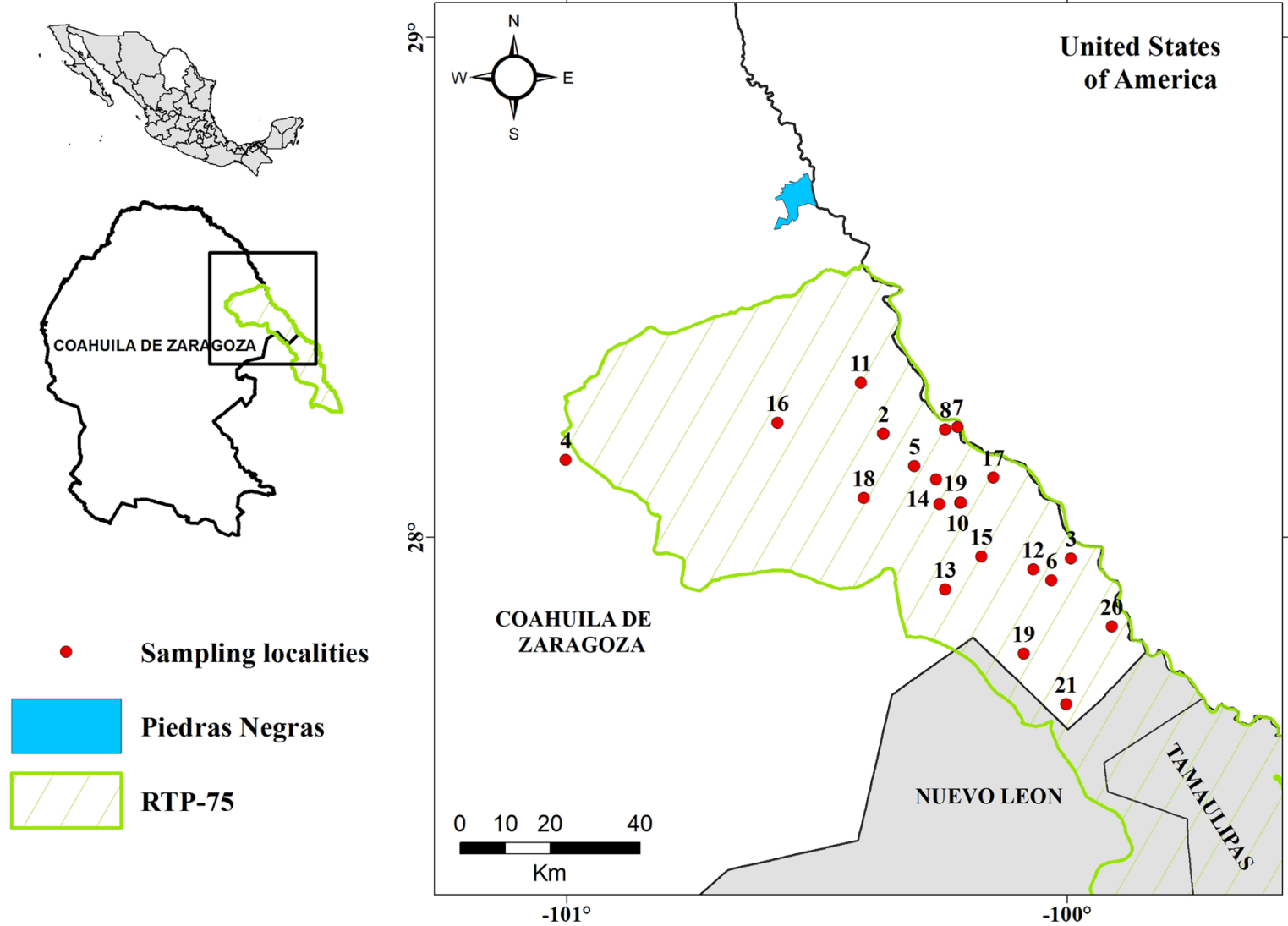

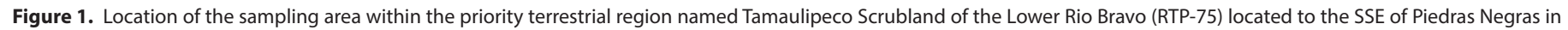
northeastern Coahuila. The name and location of collection sites are detailed in Annex 1.

number of plant species (Alanis et al. 2008; Jiménez et al. 2009; Mora-Donjuán et al. 2014). It is considered that over $90 \%$ of its original surface area has been lost in Texas, while in $30 \%$ is still preserved in northern Mexico (Arriaga et al. 2000). Although no formal studies on the negative effects are currently available, it is likely that the loss mentioned above would undoubtedly jeopardize the fauna present in this type of vegetation, including mammals.

The State of Coahuila de Zaragoza is the third largest political entity in Mexico and provides a variety of suitable habitats for a great diversity of mammals due to its geographical location and unique type of vegetation. This diversity has been studied on a large scale (Sánchez-Cordero et al. 2014), but not at local scales; as a result, some regions are not well documented. In general, studies on mammals in this State are scarce compared with those available for other entities (Guevara-Chumacero et al. 2001; Islas-Sánchez 2014). The knowledge of mammals in Coahuila is summarized in a general inventory (Baker 1956) and some other inventories elaborated for particular groups and regions and reported in the gray literature (Tavizon 1998; Juarez 2006; Mata 2012; Rodriguez 2013; AguilarBucio 2014). Another piece of work focuses on the Cuatro Ciénegas Reserve (Contreras-Balderas et al. 2007). This area is one of the regions with the most intense hunting activity in the country, and includes an estimated 4.4 million hectares where hunting is practiced. Coahuila has a record of over one thousand ranches and ejidos with Wildlife Man- agement and Exploitation Units (UMA in Spanish); Acuña, Zaragoza, Guerrero, Villa Union, Jimenez and Nava are the municipalities where the main hunting associations and guides are located (CONABIO 2012).

Due to these intense human activities in the area and the limited local knowledge of the mammalian fauna in the State, it is imperative to produce solid and reliable information concerning the wild populations of mammals that are found at local scales, since the lack of this basic information may result in the inadequate management of natural resources aiming at conservation and sustainable use in the area. For this purpose, this study recorded the richness of wild mammals present in an area comprising two municipalities in northeastern Coahuila, Mexico.

\section{Materials and Methods.}

Study area. The sampling area is located $70 \mathrm{~km}$ SSE of Piedras Negras in the municipalities of Guerrero and Hidalgo, in northeastern Coahuila, Mexico. It has an area of approximately $1,500 \mathrm{~km}^{2}$ and the dominant vegetation type is the Tamaulipeco thorny scrubland plus small patches of xeric mesquite scrublands, oak forests and natural grassland. The area is located within one of the regions classified by the Mexican government as a priority terrestrial region called Tamaulipeco Scrubland of the Lower Rio Bravo (RTP-75) through the National Commission for the Knowledge and Use of Biodiversity (Figure 1). This scrubland vegetation is dominated by deciduous thorny species most of the year. 


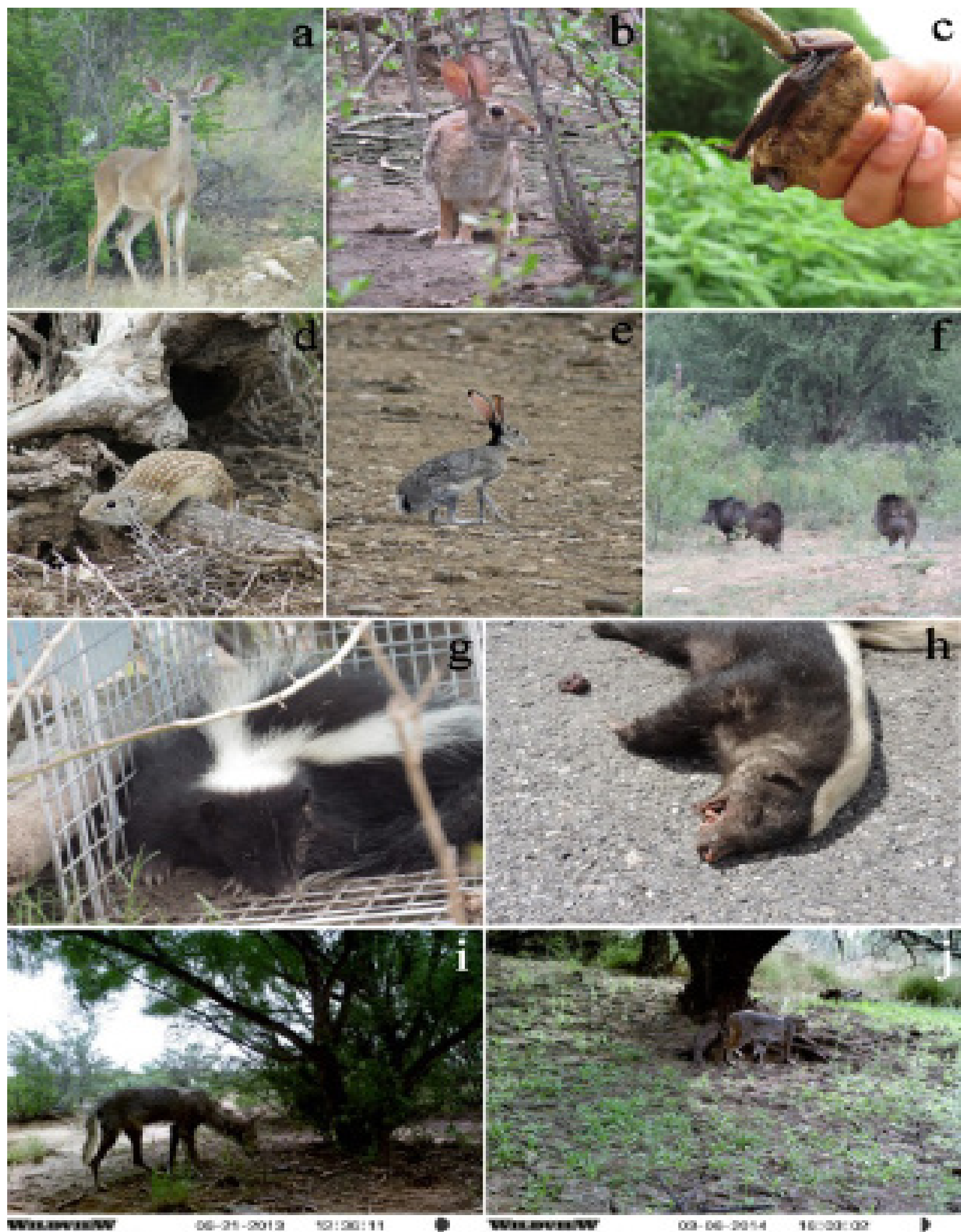

Figure 2. Some species recorded by sighting and camera traps in the study area. A) Odocoileus virginianus, B) Sylvilagus audubonii, C) Eptesicus fuscus, D) Ictidomys mexicanus, E) Lepus californicus, F) Dicotyles angulatus, G) Mephitis mephitis, H) Conepatus leuconotus, I) Canis latrans, and J) Lynx rufus. 
Table 1. Figures used for each type of evidence to calculate the occurrence index. Modified from Boddicker et al. (2002). The "Type of Evidence" column has been added.

\begin{tabular}{|c|c|c|c|}
\hline $\begin{array}{l}\text { Type of } \\
\text { Evidence }\end{array}$ & $\begin{array}{l}\text { Quality of } \\
\text { Evidence }\end{array}$ & Type of Record & Magnitude \\
\hline \multirow{2}{*}{ Direct } & \multirow{2}{*}{ Unambiguous } & Collected species & 10 \\
\hline & & Observed species & 10 \\
\hline \multirow{8}{*}{ Indirect } & \multirow{6}{*}{ High quality } & Bones & 5 \\
\hline & & Hair & 5 \\
\hline & & $\begin{array}{l}\text { Identification by local } \\
\text { residents }\end{array}$ & 5 \\
\hline & & Footprints & 5 \\
\hline & & $\begin{array}{l}\text { Vocalizations and } \\
\text { odoriferous substances }\end{array}$ & 5 \\
\hline & & $\begin{array}{l}\text { Beds, burrows, trails, } \\
\text { scratches and excavations }\end{array}$ & 4 \\
\hline & \multirow{2}{*}{ Low quality } & Feces & 4 \\
\hline & & Food remains & 4 \\
\hline
\end{tabular}

The species that predominate are the gavia or huizache (Acacia sp.), paloverde (Cercidium sp.), cenizo (Leucophyllum sp.), mesquite (Prosopis sp.), amargoso (Castela tortuosa) and abrojos (Condalia sp: INEGI 2009; Mora-Donjuán et al. 2014). The physiography of the study area is dominated by prairies and plains, the climate is dry and warm with a mean annual temperature above $22^{\circ} \mathrm{C}$, and with summer and winter rainfall greater than $18 \%$ per year (Arriaga et al. 2000).

Methodology and Data Analysis. Three field trips were conducted in October 2013, March 2014 and June 2014, irregularly distributed in relation to the climatic season, giving a total of 34 days of sampling. Recordings were made using capture and trace methods. The traps used to capture non-flying small mammals (weight $<500 \mathrm{~g}$ ), were 110 Sherman traps baited with a mixture of oat and vanilla extract placed at random along transects (such as ravines, fallen logs, close to potential burrows and in vegetated areas). The number of transects varied at each sampling site depending on the conditions of each. The age, sex and reproductive status of all specimens captured were recorded before releasing them. Some of these individuals were collected as reference specimens and were prepared conventionally as skin, skeleton, and tissue for deposit and cataloguing in the National Collection of Mammals (CNMA) of the Institute of Biology, Universidad Nacional Autónoma de México. All captured specimens were handled according to the guidelines of the American Society of Mammalogists (Sikes et al. 2011) using the scientific collector license FAUT-0070.

For flying mammals, it was not possible to conduct night captures with mist nets; hence, only daytime searches were carried out in potential shelters such as abandoned buildings, trees and caves. As regards medium-sized and large mammals (weight $>500 \mathrm{~g}$ ), six Tomahawk traps of various dimensions baited with sardine were placed at distances of at least $400 \mathrm{~m}$. In addition, 16 WVL WF118i_halfshutter camera traps with motion sensor were placed in water bodies or areas identified as animals trails by the continuous identification of tracks. The camera traps were set to oper- ate 24 hours a day and with a minimum delay of 20 seconds between photographs. One day ( 24 hours) was regarded as one sampling event per camera trap station, considering as independent captures those individual photographs or groups of photographs by species recorded by each camera trap station in a single sampling event (Yasuda 2004). As a supplement, daytime surveys were conducted, each lasting between six to eight hours, across random free transects measuring one to five $\mathrm{km}$ long (Wilson and Delahay 2001), where sightings were recorded photographically using conventional cameras. Traces were also searched in these same surveys, including excreta, footprints, and remains such as hair and horns, all of which were identified through specialized guides (Aranda 2012; Elizalde-Arellano et al. 2014). From this evidence, the traces recorded were counted; if more than one was found in the same area, this was considered as a single record to avoid an overestimate of the data (Wilson and Delahay 2001). Bone remains and roadkill specimens of medium-sized and large species were collected, taking samples of tissue, and the skin and skeleton were prepared in the conventional manner for deposit in the biological collection. All specimens were identified using specialized guides (Hall 1981; Alvarez et al. 1994; Villa y Cervantes 2003; Medellín et al. 2008) and by comparisons with CNMA voucher specimens.

To confirm the presence of the species, we used the occurrence index proposed by Boddicker et al. (2002). This index assigns values to the various types of evidence: ambiguous, high-quality and low-quality, and assesses the presence of species from the accumulation of these types of evidence (Table 1). When the cumulative points reach a value of 10 , it is concluded that the species is present on the site. The nomenclature used for the species was as proposed by Ramírez-Pulido et al. (2014).

The species richness of mammals in the study area was calculated using direct data through the Margalef index with the formula $D M g=S-1 / 1 n N$, where $S$ is the number of species and $\mathrm{N}$ is the total number of individuals (Moreno 2001). In addition, dominance and evenness were estimated through the Shannon-Wiener and Simpson indices (Moreno 2001) for small, medium-sized and large mammals separately (Monroy-Vilchis et al. 2011).

\section{Results}

A sampling effort of 34 days resulted in the recording of 33 mammal species in the study area, belonging to 7 orders, 16 families and 30 genera (Table 2). The orders best represented were Carnivora and Rodentia, with $39.4 \%$ and 30.3 $\%$ of the total number of species, respectively; the families with the largest number of species were Felidae, Heteromyidae and Cricetidae, with $12.1 \%$ each. A total of 709 records were obtained, 510 of which were direct and 199 indirect.

The small mammals captured (196 individuals) correspond to the orders Rodentia and Chiroptera, belonging to five families and 12 species. Ten species of rodents were recorded, the species with the highest number of records 


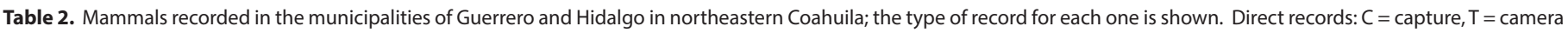

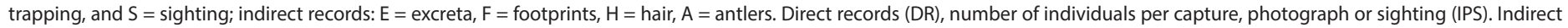
records (IR) and number of indirect records (NIR).

\begin{tabular}{|c|c|c|c|c|c|c|}
\hline Order & Family & Species & TRD & IPS & IR & NIR \\
\hline Didelphimorphia & Didelphidae & Didelphis virginiana & C & 1 & $E, F$ & 1 \\
\hline Cingulata & Dasypodidae & Dasypus novemcinctus & - & 0 & $\mathrm{~F}$ & 1 \\
\hline \multirow[t]{3}{*}{ Lagomorpha } & Leporidae & Lepus californicus & $C, S$ & 26 & - & - \\
\hline & & Sylvilagus audubonii & $C, T, S$ & 19 & - & - \\
\hline & & Sylvilagus floridanus & $C, T, S$ & 35 & - & - \\
\hline \multirow[t]{10}{*}{ Rodentia } & Sciuridae & Sciurus sp. & $\mathrm{C}$ & 1 & - & - \\
\hline & & Ictidomys mexicanus & $C, S$ & 17 & $E, F$ & 8 \\
\hline & Cricetidae & Sigmodon hispidus & $\mathrm{C}$ & 7 & - & - \\
\hline & & Neotoma micropus & $\mathrm{C}$ & 4 & - & - \\
\hline & & Onychomys leucogaster & $\mathrm{C}$ & 12 & - & - \\
\hline & & Peromyscus leucopus & $\mathrm{C}$ & 85 & - & - \\
\hline & Heteromyidae & Perognathus merriami & $\mathrm{C}$ & 21 & - & - \\
\hline & & Chaetodipus hispidus & $C$ & 11 & - & - \\
\hline & & Dipodomys merriami & $C$ & 31 & - & - \\
\hline & & Dipodomys ordii & C & 2 & - & - \\
\hline \multirow[t]{13}{*}{ Carnivora } & Felidae & Lynx rufus & $\mathrm{T}, \mathrm{S}$ & 3 & $E, F$ & 10 \\
\hline & & Puma concolor & - & 0 & $E, F$ & 5 \\
\hline & & Herpailurus yagouaroundi & $S$ & 2 & $\mathrm{~F}$ & 1 \\
\hline & & Leopardus weidii & - & 0 & $E, F$ & 2 \\
\hline & Canidae & Canis latrans & $\mathrm{T}, \mathrm{S}$ & 21 & $E, F$ & 48 \\
\hline & & Urocyon cinereoargenteus & $C, S$ & 7 & $E, F$ & 6 \\
\hline & Mustelidae & Taxidea taxus & $S$ & 1 & - & - \\
\hline & Mephitidae & Conepatus leuconotus & $\mathrm{C}$ & 1 & $\mathrm{~F}$ & 1 \\
\hline & & Mephitis mephitis & $\mathrm{C}$ & 1 & - & - \\
\hline & Procyonidae & Bassariscus astutus & S & 1 & $\mathrm{E}$ & 1 \\
\hline & & Nasua narica & - & 0 & $E, F$ & 2 \\
\hline & & Procyon lotor & $C, T$ & 5 & $\mathrm{E}, \mathrm{F}, \mathrm{H}$ & 25 \\
\hline & Ursidae & Ursus americanus & - & 0 & $\mathrm{E}, \mathrm{H}$ & 11 \\
\hline \multirow[t]{2}{*}{ Chiroptera } & Molossidae & Tadarida brasiliensis & C & 3 & - & - \\
\hline & Verpertilionidae & Eptesicus fuscus & $\mathrm{C}$ & 2 & - & - \\
\hline \multirow[t]{3}{*}{ Artiodactyla } & Tayassuidae & Dicotyles angulatus & $\mathrm{C}, \mathrm{T}, \mathrm{S}$ & 110 & $E, F, H$ & 15 \\
\hline & Cervidae & Odocoileus virginianus & $C, T, S$ & 81 & $E, F, A$ & 61 \\
\hline & & Odocoileus hemionus & - & 0 & $A$ & 1 \\
\hline Total records & & & & 510 & & 199 \\
\hline
\end{tabular}

being Peromyscus leucopus, Dipodomys merriami and Perognathus merriami (85, 31 and 21 individuals, respectively). One specimen of the genus Sciurus could not be identified to species because it was a poorly preserved roadkill specimen. On the other hand, the bat species found in shelters were Eptesicus fuscus within cavities at the base of a dead tree, and Tadarida brasiliensis inside an abandoned building.

The medium-sized and large mammals (505 records in total) belong to five orders, 11 families and 21 species. The species with the highest number of direct records were Dicotyles angulatus (110), Odocoileus virginianus (81) and Sylvilagus floridanus (35, Figure 2). The occurrence index by Boddicker et al. (2002) confirmed the presence of all species except Dasypus novemcinctus, Puma concolor, Conepatus leuconotus, Nasua narica and Ursus americanus, which were identified by indirect methods only.

A total of 39 specimens were deposited in the National Collection of Mammals (CNMA; Annex 1). Of the total species recorded, four are under some protection category by the Mexican government according to NOM-059-2010 (SEMARNAT 2010): Herpailurus yagouaroundi and Taxidea taxus as "threatened", and Ursus americanus and Leopardus weidii in the "special protection" category. On the other hand, the species Lynx rufus, Puma concolor, Herpailurus yagouaroundi, and Ursus americanus are listed in Appendix II of the Convention on International Trade in Endangered Species of Wild Fauna and Flora 
(CITES), while Leopardus weidii is listed in Appendix I (2016). The only endemic species recorded was Ictidomys mexicanus.

The Margalef index (5.13) revealed that the total diversity in the area is high. The Simpson index for small mammals (0.241) points to a greater dominance of the most abundant species relative to medium-sized and large mammals (0.215). On the other hand, the Shannon-Wiener index showed that the evenness between species was lower for small mammals (1.821) relative to medium-sized and large mammals (1.858).

\section{Discussion}

Despite the fact that Mexico still preserves $30 \%$ of the surface area originally covered with Tamaulipeco thorny scrubland, it is considered that there is an insufficient knowledge about the fauna that inhabits it (Arriaga et al. 2000). In addition, the low number of studies that are carried out in Coahuila due to safety issues and the low number of protected natural areas in the state highlight the importance of this work.

Coahuila is home to 107 species of mammals: 80 terrestrial and 27 flying ones (Sánchez-Cordero et al. 2014). In all, $31.8 \%$ of the mammal fauna of the State was recorded in the study area, demonstrating the high diversity in the area supported by the Margalef index (5.13). The three rodent species with the highest number of records are widely distributed species. P. leucopus is highly tolerant to various environmental conditions such as those that characterize the study area, while $D$. merriami is considered to be locally abundant in other studies (Castillo 2005; Chávez and Espinosa 2005; Frisch-Jordan and Arita 2005).

Ictidomys mexicanus was the only endemic species recorded (Ramírez-Pulido et al. 2014), with only three individuals captured. The number of sightings (13) was higher, supported by indirect records including excreta and burrows; this suggests a high abundance of the species in the area. This is consistent with other studies that indicate that this species is relatively abundant across its areas of distribution (Ceballos and Galindo 1984; Valdez and Ceballos 1991).

The daytime searches of bat shelters detected an abandoned building used as a warehouse that was inhabited by a large colony of at least 15 individuals of Tadarida brasiliensis. Due to the difficulty of capturing all individuals and that this a "segregationist" species, i. e., it shares its shelters with just a few species (Arita 1993), it is considered that the whole colony belonged to this species only. The second Chiroptera species recorded was Eptesicus fuscus with about four individuals observed and captured inside cavities at the base of a dead tree, with no other structure close to it. This type of shelter is characteristic of the species (Tellez-Giron 2005).

The occurrence index by Boddicker et al. (2002) did not confirm the presence of five species (Dasypus novemcinctus, Nasua narica, Conepatus leuconotus, Puma concolor and Ursus americanus), since these were detected through a low number of indirect records. However, the traces observed possess particular characteristics that facilitate their identification. D. novemcinctus leaves a characteristic and unmistakable trail of footprints; the unique features of these fingerprints derive from fingers being short with long thick claws with rounded tips; in addition, in some cases the drag of the tail leaves a trace in soil (Aranda 2012). In P. concolor, the tracks could only be misidentified with those of the jaguar (Panthera onca) because of the similar size of the fingerprints. However, it was considered that the habitat is more favorable for the cougar, in addition to the fact that several specimens of this species have been observed by local inhabitants and workers. The footprints of $C$. leuconotus are similar to those of $C$. semistriatus, but these two species have supplementary distributions and the study area coincides with the distribution of $C$. leuconotus (Aranda 2012). This was confirmed by a roadkill individual found in a survey trip to the site (Figure $2 \mathrm{H}$ ). In the case of $\mathrm{N}$. narica and $U$. americanus, evidence records are scarce. In the case of N. narica, these comprise only two traces; in the case of $U$. americanus, in presumed excreta. The margay (Leopardus weidii) was recorded based on two prints that match the characteristics and size of the species, although these can be confused with domestic cat traces (Aranda 2012), no margay specimens were observed in the area.

The large number of records of Dicotyles angulatus ( $n=$ 110 ) and Odocoileus virginianus $(n=81)$ is due to the fact that the study area is located within a hunting zone where these are the main species used. A skull and vertebrae of one specimen were collected which were subsequently identified as a mule deer (Odocoileus hemionus). The identification is based on the comparison with specimens in the National Collection of Mammals, where the size of the lacrimal bone allowed the identification as O. hemionus. The mule deer lives in isolated geographical patches, and hunting is permitted under the "special license" modality (Galindo-Leal 1993). However, the hunting ranches in the area do not report the mule deer among the game species used.

Hunting is an activity with strong cultural roots that led to the disappearance or marked decline of the local populations of some species; as a result, the mule deer has been subject to strict regulation, including the creation of hunting zones (SAHR 1993). This type of scheme has been widely popularized in the northern States of Mexico and covers an area of more than 18 million hectares, making it one of the most important sources of income in the region. Recently, hunting has been linked to a number of benefits for conservation because it allows the controlled use of the resource in extensive areas and represents a significant income that allows managing the area to preserve its environmental quality in terms of vegetation that is favorable for the presence of game animals (2010 Rengifo-Gallego). The maintenance or establishment of a suitable habitat for game species (natural vegetation within the agricultural 
matrix, mosaic landscape or boundaries), as well as the supply of food and water, seem to favor other species as well (Arroyo et al. 2013). In our study area, the management and conservation of the habitat benefits not only the game species but also the rest of species present in the area. This is reflected in the high number of species recorded and in the presence of large carnivores such as the black bear $(U$. americanus) and the cougar (P. concolor).

\section{Acknowledgments}

To M. Espino Chávez, E. Diaz Islas and O. J. Vera Mackintosh of TEO Consultoría Ambiental S. C., and to M. C. Rodriguez, for the support and logistics for the collection of field data. To L. Juárez and L. Flores for their assistance during field work. To F. A. Cervantes for facilitating the processing and deposit of specimens in the National Collection of Mammals (CNMA). To D. Vilchis Rocha for the comments that helped improve the text. María Elena Sánchez-Salazar translated the manuscript into English with support of THERYA through a CONACYT grant

\section{Literature cited}

Aguilar-Buclo, L. M. 2014. Monitoreo de la diversidad, abundancia y riqueza de especies de fauna silvestre en el proyecto minero "Carlos II", Palaú, Coahuila, México. Tesis de licenciatura. Universidad Autónoma Agraria Antonio Narro. Saltillo, México.

Alanís, E., J. Jiménez, O. A. Aguirre, J. E. Treviño, E. Jurado, and M. A. GonZÁlez. 2008. Efecto del uso del suelo en la fitodiversidad del matorral espinoso tamaulipeco. Ciencia Universidad Nacional Autónoma de Nuevo León 1:56-62.

Álvarez, T., T. Álvarez-CastañedA, AND J. C. López-VIDAl. 1994. Claves para murciélagos mexicanos. Centro de Investigaciones del Noroeste, S. C. and Escuela Nacional de Ciencias Biológicas del Instituto Politécnico Nacional. La Paz, México.

ARANDA, J. M. S. 2012. Manual para el rastreo de mamíferos silvestres de México. Comisión Nacional para el Conocimiento y Uso de la Biodiversidad. Ciudad de México, México.

ARITA, H. T. 1993. Conservation biology of the cave bats of Mexico. Journal of Mammalogy 74:693-702.

Arriaga, L., J. M. Espinoza, C. Aguilar, E. Martínez, L. Gómez, and E. LOA (coord.). 2000. Regiones terrestres prioritarias de México. Comisión Nacional para el Conocimiento y uso de la Biodiversidad. Ciudad de México, México.

Arroyo, B., M. Delibes-Mateos, J. Caro, A. Estrada, F. Mougeot, S. Díaz-Fernández, F. Casas, and J. Viñuela. 2013. Efecto de la gestión para las especies de caza menor sobre la fauna no cinegética. Ecosistemas 22:27-32.

BAKER, R. H. 1956. Mammals of Coahuila, Mexico. University Kansas Publications, Museum Natural History 9:125-335.

BoddiCKer, M., J. J. RodrigueZ, AND J. Amanzo. 2002. Indices for assessment and monitoring of large mammals within an adaptive management framework. Environmental Monitoring and Assessment 76:105-23.

CASTILLO, R. A. 2005. Dipodomys merriami. Pp. 616- 617 in Los Mamíferos Silvestres de México (Ceballos, G., and G. Oliva, Coord.). Comisión Nacional para el Conocimiento y Uso de la Biodiversidad, Fondo de Cultura Económica. Ciudad de México, México.
Ceballos, G., and C. Galindo. 1984. Mamíferos Silvestres de la Cuenca de México. Editorial Limusa. Ciudad de México, México. CITES. 2016. Convención Internacional sobre el Comercio de Especies Amenazadas de Fauna y Flora. Apéndices I, II and II. Disponible en https://cites.org/esp/app/appendices.php Última consulta 16 junio 2016.

Chávez, C. B., and L. A. Espinosa. 2005. Peromyscus leucopus. Pp. 744-745 en Los Mamíferos Silvestres de México (Ceballos, G. and G. Oliva, Coord.). Comisión Nacional para el Conocimiento y Uso de la Biodiversidad, Fondo de Cultura Económica. Ciudad de México, México.

CONABIO. 2012. Proyecto de Evaluación de las Unidades de Manejo para la Conservación de la Vida Silvestre (UMA) (19972008). Resultados de la Fase I: Gestión y Administración. Proyectos CONABIO: HV003, HV004, HV007, HV012 y HV019. Disponible en http://www.biodiversidad.gob.mx/usos/ UMAs_pdf/Informe_CONABIO_Proyecto_UMA_FASE_I.pdf

Contreras-Balderas, A. J., D. J. Hafner, J. H. Lopez-Soto, J. M. Torres-Ayala, and S. Contreras-Arquieta. 2007. Mammals of the Cuatro Ciénegas basin, Coahuila, México. The Southwestern Naturalist 52:400-409.

Elizalde-Arellano, C., J. C. López-Vidal, L. Hernández, J. W. Laundré, and F. M. Morales-MejíA. 2014. Bases para el monitoreo de dos especies de carnívoros medianos en la Reserva de la Biosfera de Mapimí, Durango. Instituto Politécnico Nacional, Escuela Nacional de Ciencias Biológicas. Guía de mamíferos de la Reserva de la Biosfera de Mapimí SNIB-CONABIO, proyecto GT022. Ciudad de México, México. Disponible en http:// www.conabio.gob.mx/institucion/proyectos/resultados/ GT022_Anexo_Guia_Mamiferos.pdf

Frisch-JoRdÁn, A., AND H. T. ARITA. 2005. Perognathus merriami. Pp. 655-656 en Los Mamíferos Silvestres de México (Ceballos, G., and G. Oliva, Coord.). Comisión Nacional para el Conocimiento y Uso de la Biodiversidad, Fondo de Cultura Económica. Ciudad de México, México.

Galindo LeaL, C. 1993. Densidades poblacionales de los venados cola blanca, cola negra y bura en Norteamérica. Pp. 371-391 en Avances en el estudio de los Mamíferos de México. (Medellín, R. A., and G. Ceballos, eds). Publicaciones especiales, Vol. 1, Asociación Mexicana de Mastozoología, A. C. Ciudad de México, México.

Guevara-Chumacero, L. M., R. López-Wilchis, and V. Sánchez-Cordero. 2001. 105 años de investigación mastozoológica en México (1890-1995): una revisión de sus enfoques y tendencias. Acta Zoológica Mexicana (n. s.) 83:35-72.

HALL, E. R. 1981. The mammals of North America. John Wiley, Hobaken, New Jersey, U. S. A.

Instituto Nacional De Estadística y Geografía (INEGI). 2009. Guía para la interpretación de cartografía uso del suelo y vegetación Escala 1:250 000 Serie III. Instituto Nacional de Estadística y Geografía. Ciudad de México, México.

Islas-SánChez, L. 2014. Estado del conocimiento actual de los mamíferos terrestres en México. Tesis Facultad de ciencias biológicas y agropecuarias. Universidad Veracruzana. Tuxpan, México.

Jiménez, J., E. Alanís, O. Aguirre, M. Pando, and M. A. González. 2009. Análisis sobre el efecto del uso del suelo en la diversidad estructural del matorral espinoso tamaulipeco. Madera y Bosques 3:5-20. 
Jiménez, J., E. Alanís-Rodríguez, J. L. Ruiz-González, M. A. GonzálezTagle, J. I. Yerena-Yamalle, and G. J. Alanís-Flores. 2012. Diversidad de la regeneración leñosa del matorral espinoso tamaulipeco con historial agrícola en el noreste de México. Ciencia Universidad Nacional Autónoma de Nuevo León 58:66-71.

JUÁREZ, D. J. 2006. Diversidad de pequeños mamíferos asociados a poblaciones de Pinus pinceana Gordon en Coahuila y Zacatecas. Tesis de licenciatura. Universidad Autónoma Agraria Antonio Narro. Saltillo, México.

MATA, G. C. 2012. Abundancia relativa de mamíferos terrestres Grandes y Medianos en el Área Reforestada de la Sierra de Zapalinamé, Coahuila México. Tesis de licenciatura Universidad Autónoma Agraria Antonio Narro. Saltillo, México.

Medellín, R. A., H. T. Arita, and O. Sánchez. 2008. Identificación de los Murciélagos de México, claves de campo. Segunda Edición. Asociación Mexicana de Mastozoología, Publicaciones especiales. Ciudad de México, México.

Monroy-Vilchis, O., M. M. Zarco-González, J. Ramírez-Pulido, and U. Aguilera-ReYes. 2011. Diversidad de mamíferos de la Reserva Natural Sierra Nanchititla, México. Revista Mexicana de Biodiversidad 82:237-248.

Mora-Donjuán, C. A., E. A. Rubio-Camacho, E. Alanís-Rodríguez, J. Jiménez-Pérez, M. A. González-Tagle, J. M. Mata-Balderas, and A. Mora-Olivo. 2014. Composición y diversidad vegetal de un área de Matorral Desértico Micrófilo con historial pecuario en el noreste de México. Polibotánica 38:53-66.

Moreno, C. 2001. Métodos para medir la biodiversidad. M\&TManuales y Tesis SEA. Zaragoza, España.

Ramírez-Pulido, J., N. González-Ruiz, A. L. Gardner, and J. ArroyoCABRAles. 2014. List of recent land mammals of México, 2014. Special Publications, Museum of Texas Tech University 63:1-69.

Rengifo-Gallego, J. I. 2010. Caza y turismo cinegético como instrumentos para la conservación de la naturaleza. Anales de Geografía 30:163-186.

Rodríguez-Rodríguez, S. A. 2013. Estimación de abundancia relativa de mamíferos terrestres grandes y medianos mediante fototrampeo en el área de reforestación Zapalinamé, Saltillo, Coahuila. Tesis de licenciatura. Universidad Autónoma Agraria Antonio Narro. Saltillo, México.

RzEDOWSKI, J. 2006. Vegetación de México. 1ra. ed. digital. Comisión Nacional para el Conocimiento y Uso de la Biodiversidad. Ciudad de México, México.

Sánchez-Cordero, V., F. Botello, J. J. Flores-Martínez, R. A. GómezRodríguez, L. Guevara, G. Gutiérrez-Granados, G., and A. RodríguezMoreno. 2014. Biodiversidad de Chordata (Mammalia) en México. Revista Mexicana de Biodiversidad, Supl. 85:S496-S504.

SARH. 1993. Plan Maestro para la instalación y operación de ejidos cinegéticos: Viabilidad Socioeconómica y diagnóstico técnico. Instituto Nacional de Ecología. Subsecretaria Forestal y de Fauna Silvestre. Disponible en http://repositorio.inecc. gob.mx/ae2/ae_354.333_m495-8_t.2.pdf

SEMARNAT. 2010. Norma Oficial Mexicana NOM-059ECOL-2010. Protección ambiental. Especies nativas de México de flora y fauna silvestres. Categorías de riesgo y especificaciones para su inclusión, exclusión o cambio. Lista de especies en riesgo. Diario Oficial de la Federación. Ciudad de México, México.
Sikes, R. S., W. L. Gannon, and The Animal Care and Use Of The American Society Of Mammalogists. 2011. Guidelines of the American Society of Mammalogists for the use of wild animals in research. Journal of Mammalogy 92:235-253.

TAvizon, G. J. 1998. Estudio del nicho alimenticio de los mamíferos depredadores del orden Carnívora en la Sierra del Carmen, Noroeste de Coahuila, México. Tesis de posgrado. Universidad Autónoma de Nuevo León. Facultad de Ciencias Biológicas. Monterrey, México.

Tellez-Girón, G. 2005. Eptesicus fuscus. Pp. 263- 264 in Los Mamíferos Silvestres de México (Ceballos, G., and G. Oliva, Coord.). Comisión Nacional para el Conocimiento y Uso de la Biodiversidad, Fondo de Cultura Económica. Ciudad de México, México.

VAldÉz, M., AND G. Ceballos. 1991. Historia natural, alimentación y reproducción de la ardilla terrestre (Spermophilus mexicanus) en una pradera intermontana. Acta Zoológica Mexicana ( $\mathrm{n}$. s.) 43:1-31.

Villa, R. B., and F. A. Cervantes. 2003. Los mamíferos de México. Grupo Editorial Iberoamericana, Instituto de Biología, Universidad Nacional Autónoma de México. Ciudad de México, México.

Wilson, G. J., and R. J. Delahay. 2001. A review of methods to estimate the abundance of terrestrial carnivores using field signs and observation. Wildlife Research 28:151-164.

YASUDA, M. 2004. Monitoring diversity and abundance of mammals with camera traps: a case study on Mount Tsukuba, central Japan. Mammal Study 29:37-46.

Associated editor: Consuelo Lorenzo

Submitted: September 23, 2016; Reviewed: October 31, 2016;

Accepted: December 6, 2016; Published on line: January 24, 2017. 
Appendix 1. Species registered per locality, for the collected specimens the catalog number of the reference at the National Mammal Collection (CNMA), Institute of Biology, UNAM, is given. The rest of the records are indirect, as well as sighting and phototrap.

Locality 1. 5.25 km NW La Burra (Trinidad), Mpio. Guer-

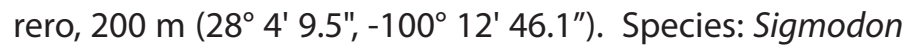
hispidus (CNMA 47022), Canis latrans, Chaetodipus hispidus (CNMA 47014), Conepatus leuconotus, Dasypus novemcinctus, Dicotyles angulatus, Dipodomys merriami, Dipodomys ordii (CNMA 47012, 47013), Ictidomys mexicanus, Lepus californicus, Lynx rufus, Mephitis mephitis, Odocoileus virginianus, Onychomys leucogaster, Perognathus merriami, Peromyscus leucopus (CNMA 47020, 47021), Procyon lotor, Puma concolor, Sigmodon hispidus, Sylvilagus audubonii, Sylvilagus floridanus, Urocyon cinereoargenteus, Ursus americanus.

Locality 2. 9.5 km NW El Gato, Mpio. Guerrero, $224 \mathrm{~m}$ (28 $\left.12^{\prime} 26.4^{\prime \prime},-100^{\circ} 22^{\prime} 3.4^{\prime \prime}\right)$. Species: Onychomys leucogaster (CNMA 47016), Canis latrans, Dicotyles angulatus (CNMA 46994, 46995), Dipodomys merriami (CNMA 47011), Ictidomys mexicanus, Lepus californicus, Odocoileus virginianus (CNMA 47002-47007), Perognathus merriami (CNMA 47015), Peromyscus leucopus (CNMA 47017 to 47019), Sylvilagus audubonii, Sylvilagus floridanus, Urocyon cinereoargenteus.

Locality 3. 4.25 km SW Santa Eulalia, Mpio. Hidalgo, 217 m (27 57' 28.53", -99 59' 31.08"). Species: Canis latrans (CNMA 46984).

Locality 4. 5.75 km NNW La Estancia, Mpio. Guerrero, 186 m (28 9' 19.3", -1010 0' 9.8"). Species: Procyon lotor (CNMA 46985).

Locality 5. 1.5 km NE El Gato, Mpio. Guerrero, $235 \mathrm{~m}$ (28 $\left.8^{\circ} 35.2^{\prime \prime},-100^{\circ} 18^{\prime} 18.7^{\prime \prime}\right)$. Species: Procyon lotor (CNMA 46986), Canis latrans, Dicotyles angulatus, Neotoma micropus, Odocoileus virginianus (CNMA 47008), Ursus americanus.

Locality 6. 5 km SSE San Francisco, Mpio. Hidalgo, 205 m ( $27^{\circ} 54^{\prime} 50.9^{\prime \prime},-100^{\circ} 1$ ' 51.2"). Species: Tadarida brasiliensis (CNMA 47009, 47010), Canis latrans, Lepus californicus, Odocoileus virginianus, Sylvilagus audubonii.

Locality 7. 12.25 km NNW La Estancia, Mpio. Guerrero, $190 \mathrm{~m}$ (28 $\left.18^{\circ} 14.3^{\prime \prime},-100^{\circ} 13^{\prime} 7.3^{\prime \prime}\right)$. Species: Dicotyles angulatus (CNMA 46987), Lynx rufus, Sylvilagus audobonii, Tadarida brasiliensis.

Locality 8. 11.75 km NNW La Estancia, Mpio. Guerrero, 190 m (28 12' 58.5", -100¹4'37.5"). Species: Dicotyles angulatus (CNMA 46988 to 46990, 46993), Canis latrans, Herpailurus yagouaroundi, Ictidomys mexicanus, Lepus californicus, Lynx rufus, Nasua narica, Odocoileus hemionus, Odocoileus virginianus (CNMA 47000), Peromyscus leucopus, Procyon lotor, Sylvilagus audubonii, Sylvilagus floridanus, Urocyon cinereoargenteus.
Locality 9. 5.25 km SSW La Estancia, Mpio. Guerrero, 208 m (28 4' 9.8", - $\left.100^{\circ} 12^{\prime} 44.9^{\prime \prime}\right)$. Species: Dicotyles angulatus (CNMA 46991), Lepus californicus, Odocoileus virginianus.

Locality 10. 6.25 km SW La Estancia, Mpio. Guerrero, 212 m (28 4' 1.4", - $\left.100^{\circ} 15^{\prime} 16.8^{\prime \prime}\right)$. Species: Dicotyles angulatus (CNMA 46992), Canis latrans, Dipodomys ordii, Lepus californicus, Lynx rufus, Neotoma micropus, Odocoileus virginianus, Procyon lotor, Puma concolor, Sylvilagus audubonii, Sylvilagus floridanus.

Locality 11. 3.5 km W Guerrero, Mpio. Guerrero, $239 \mathrm{~m}$ (28 18' 35.1", -100 24' 43.0"). Species: Dicotyles angulatus (CNMA 46996), Bassariscus astutus, Canis latrans, Didelphis virginiana, Dipodomys merriami, Herpailurus yagouaroundi, Ictidomys mexicanus, Leopardus weidii, Lepus californicus, Odocoileus virginianus, Perognathus merriami, Peromyscus leucopus, Procyon lotor, Sylvilagus floridanus, Urocyon cinereoargenteus, Ursus americanus.

Locality 12. $7.25 \mathrm{Km}$ ESE San Enrique, Mpio. Hidalgo (27 $\left.56^{\prime} 10.7^{\prime \prime},-100^{\circ} 4^{\prime} 2.7^{\prime \prime}\right)$. Species: Odocoileus virginianus (CNMA 46998), Canis latrans, Dicotyles angulatus, Ictidomys mexicanus, Lepus californicus, Lynx rufus, Procyon lotor, Sylvilagus audubonii, Taxidea taxus.

Locality 13. $11.25 \mathrm{Km}$ SE San Enrique, Mpio. Hidalgo,

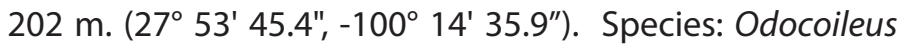
virginianus (CNMA 46999), Peromyscus leucopus.

Locality 14. 5.5 km W La Estancia, Mpio. Guerrero, 219 m (28 6' 60", - $\left.100^{\circ} 15^{\prime} 42.2^{\prime \prime}\right)$. Species: Odocoileus virginianus (CNMA 47001), Bassariscus astutus, Canis latrans, Dicotyles angulatus, Ictidomys mexicanus, Procyon lotor, Sylvilagus audobonii, Sylvilagus floridanus.

Locality 15. 5 Km NW San Enrique, Mpio. Hidalgo, $216 \mathrm{~m}$ (27 57' 43.7", -100'10' 17.9"). Species: Odocoileus hemionus (CNMA 46997), Canis latrans, Chaetodipus hispidus, Dicotyles angulatus, Dipodomys merriami, Herpailurus yagouaroundi, Lepus californicus, Lynx rufus, Neotoma micropus, Odocoileus virginianus, Onychomys leucogaster, Perognathus merriami, Peromyscus leucopus, Procyon lotor, Puma concolor, Sylvilagus audubonii, Sylvilagus floridanus, Urocyon cinereoargenteus, Ursus americanus.

Locality 16. 4.7 Km NE Santa Mónica, Mpio. Guerrero, 308 m. (28 $\left.18^{\prime} 44.6^{\prime \prime},-100^{\circ} 34^{\prime} 44.5^{\prime \prime}\right)$. Species: Dicotyles angulatus, Procyon lotor.

Locality 17. $6.17 \mathrm{Km}$ ENE La Estancia, Mpio. Guerrero, $181 \mathrm{~m}$ (28 7' 13.6", -100 8' 50.2"). Species: Canis latrans, Dicotyles angulatus, Didelphis virginiana, Eptesicus fuscus, Ictidomys mexicanus, Lepus californicus, Lynx rufus, Neotoma micropus, Odocoileus virginianus, Perognathus merriami, Peromyscus leucopus, Procyon lotor, Sylvilagus audubonii, Sylvilagus floridanus, Urocyon cinereoargenteus, Ursus americanus.

Locality 18. 2.7 Km ESE Agua Fría, Mpio. Guerrero, $266 \mathrm{~m}$ (28 $\left.04^{\prime} 45.5^{\prime \prime},-100^{\circ} 24^{\prime} 22.0^{\prime \prime}\right)$. Species: Sylvilagus audubonii. 
Locality 19. $2 \mathrm{Km} N$ Rancho Palo Blanco, Mpio. Hidalgo, 203 m (27 46' 04.7', -100 05' 11"). Species: Ursus americanus.

Locality 20. 4.97 Km NW Villa Hidalgo, Mpio. Hidalgo,

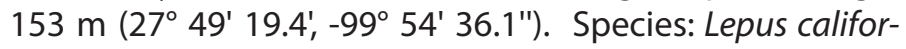
nicus.

Locality 21. $6 \mathrm{Km}$ SW Rancherías, Mpio. Hidalgo, $218 \mathrm{~m}$. (27 $\left.40^{\circ} 1.2^{\prime},-100^{\circ} 0^{\prime} 08^{\prime \prime}\right)$. Species: Odocoileus virginianus. 